\title{
Imaging the Major Salivary Glands: A Review
}

\author{
Bhaumik Joshi* \\ Consultant Oral Physician and Maxillofacial Radiologist, India
}

Submission: March 26, 2018; Published: May 09, 2018

*Corresponding author: Bhaumik Joshi, Consultant Oral Physician and Maxillofacial Radiologist, Vastral Dental Clinic and Implant Center, Ahmedabad 382418, Gujarat, India, Tel: +919566093099; Email: drbjoshi11@gmail.com

\begin{abstract}
Advances in imaging in recent years have improved the sensitivity of imaging diagnosis of diseases that involve the major salivary glands. Imaging with Ultrasound (US), plain radiography and sialography, Magnetic Resonance Imaging (MRI), Computed Tomography (CT), Cone Beam Computed Tomography (CBCT) and nuclear scintigraphy/Positron Emission Tomography (PET) play part on diagnosis and planning of further management, operative or otherwise. This article reviews the Salivary gland diseases; methods used for their imaging and indications for these methods to the principal pathological processes.
\end{abstract}

Keywords: Computed tomography; Cone beam computed tomography; Magnetic resonance imaging; Parotid gland neoplasms; Positron emission tomography; Sialography; Scintigraphy; Ultrasound

Abbreviation: US: Ultrasound; MRI: Magnetic Resonance Imaging; CT: Computed Tomography; CBCT: Cone Beam Computed Tomography; PET Positron Emission Tomography

\section{Introduction}

It is responsibility of Dental Clinician to detect disorders of the salivary glands that may be presenting with intraoral and extraoral signs and symptoms. Imaging the salivary glands play important role in this task. In recent times the advancements in the imaging modalities have made it relatively feasible to make more accurate diagnosis, when findings of these methods are combined with clinical and histopathological findings.

\section{Discussion}

\section{Salivary gland disease}

Table 1: Diseases of Salivary Glands.

\begin{tabular}{|c|c|c|}
\hline \multirow{6}{*}{$\begin{array}{l}\text { Salivary } \\
\text { Gland } \\
\text { Diseases }\end{array}$} & \multirow{2}{*}{ Inflammatory } & $\begin{array}{l}\text { Primary } \\
\quad \text { Acute \& Chronic Bacterial, Viral and } \\
\text { Fungal Sialadenitis }\end{array}$ \\
\hline & & $\begin{array}{l}\text { Secondary } \\
\text { Secondary to Trauma, Sialolith or } \\
\text { space occupying lesion }\end{array}$ \\
\hline & \multirow{2}{*}{$\begin{array}{c}\text { Non } \\
\text { Inflammatory }\end{array}$} & $\begin{array}{l}\text { Secretory } \\
\quad \text { Xerostomia, Ptylism Neurological } \\
\text { Disorder }\end{array}$ \\
\hline & & $\begin{array}{l}\text { Metabolic } \\
\quad \text { Diseases of Endocrine glands }\end{array}$ \\
\hline & \multirow{2}{*}{$\begin{array}{l}\text { Space } \\
\text { Occupying } \\
\text { Masses }\end{array}$} & Cystic \\
\hline & & $\begin{array}{l}\text { Neoplastic } \\
\quad \text { Benign Malignant }\end{array}$ \\
\hline
\end{tabular}

Disease of salivary gland may arise due to inflammatory process, non-inflammatory process or Space occupying mass. Diseases of Salivary glands present with variety of signs and symptoms including Pain, Swelling, and altered salivation presenting as either xerostomia or Ptylism. Table 1 classifies the diseases of salivary glands. The cause of swelling that appears in major salivary gland lesion can be glandular or extra-glandular Table 2 \& Table 3 represent differential diagnosis of swellings that appear in Parotid and Submandibular salivary gland region [1].

Table 2: Differential Diagnosis of swellings in Parotid Gland region.

\begin{tabular}{|c|c|c|c|}
\hline \multirow{5}{*}{$\begin{array}{c}\text { Swelling } \\
\text { of Parotid } \\
\text { Region }\end{array}$} & \multirow[t]{2}{*}{ Unilateral } & $\begin{array}{c}\text { Palpable } \\
\text { Mass }\end{array}$ & $\begin{array}{l}\text { 1. Benign Tumors like } \\
\text { Pleomorphic adenoma, Vascular } \\
\text { malformation } \\
\text { 2. Malignant Tumor like } \\
\text { Mucoepidermoid Carcinoma } \\
\text { 3. Hamartomas }\end{array}$ \\
\hline & & Diffuse & $\begin{array}{c}\text { Primary and Secondary } \\
\text { Sialdenitis }\end{array}$ \\
\hline & \multirow[t]{2}{*}{ Bilateral } & $\begin{array}{l}\text { Asymp } \\
\text { tomatic }\end{array}$ & $\begin{array}{l}\text { 1. Benign Lymphoepithelial } \\
\text { lesion } \\
\text { 2. Sjögren's Syndrome } \\
\text { 3. Drug induced Hypertrophy } \\
\text { 4. Warthin Tumor }\end{array}$ \\
\hline & & Painful & $\begin{array}{c}\text { After Radiation therapy } \\
\text { Viral Sialadenitis }\end{array}$ \\
\hline & $\begin{array}{c}\text { Not Assoc } \\
\text { iated to } \\
\text { Parotid } \\
\text { gland }\end{array}$ & \multicolumn{2}{|c|}{$\begin{array}{l}\text { 1. Masseter Hypertrophy } \\
\text { 2. Accessory Parotid } \\
\text { 3. Lesions related TMJ } \\
\text { Osteomyelitis of Ramus of Mandible } \\
\text { 5. Lymphadenitis } \\
\text { 6. Preauricular Cyst } \\
\text { 7. Infected sebaceous cyst } \\
\text { 8. Benign Lymphoid Hyperplasia } \\
\text { 9. Extra parotid tumor }\end{array}$} \\
\hline
\end{tabular}


Table 3: Differential Diagnosis of swellings in Submandibular Gland region.

\begin{tabular}{|c|c|c|c|}
\hline \multirow{4}{*}{$\begin{array}{c}\text { Swelling of } \\
\text { Submandibular } \\
\text { Region }\end{array}$} & \multirow[t]{2}{*}{ Unilateral } & $\begin{array}{l}\text { Not Associated } \\
\text { with tender } \\
\text { Lymphadenitis }\end{array}$ & $\begin{array}{l}\text { Cystic \& } \\
\text { Neoplastic } \\
\text { space } \\
\text { occupying } \\
\text { mass }\end{array}$ \\
\hline & & $\begin{array}{c}\text { Associated } \\
\text { with tender } \\
\text { Lymphadenitis }\end{array}$ & $\begin{array}{c}\text { Primary and } \\
\text { Secondary } \\
\text { Sialdenitis }\end{array}$ \\
\hline & Bilateral & \multicolumn{2}{|c|}{$\begin{array}{c}\text { Viral Sialadenitis } \\
\text { Sjögren's Syndrome }\end{array}$} \\
\hline & $\begin{array}{l}\text { Not } \\
\text { Associated to } \\
\text { Submandibular } \\
\text { gland }\end{array}$ & \multicolumn{2}{|c|}{$\begin{array}{c}\text { Submandibular space infection } \\
\text { Brachial Cleft Cyst } \\
\text { Actinomycosis } \\
\text { Tuberculosis }\end{array}$} \\
\hline
\end{tabular}

Approach for selecting Imaging modality for Salivary gland diseases

Imaging of salivary gland is helpful in Detecting site, nature and extension of lesion; evaluating the ductal morphology, selecting site of Biopsy and treatment planning. It also helps in differentiating between diffuse and focal Suppurative lesions. Depending on pathology and patient factors Selection of Imaging modality should be done. Starting point of any Salivary gland pathology imaging is plain radiography. It demonstrates Sialolith and involvement of adjacent osseous structures. If plain radiography fails to provide any information next stage of imaging is Sialography that provides morphologic information of ongoing intra glandular process. However this condition uses contrast medium which may be contraindicated in certain conditions and in these conditions the imaging should be carried out by MRI. CT and CBCT also provide information of presence and exact location of Sialolith in relation to gland being imaged. US provide information that can be helpful in differentiating the nature of lesion associated with the salivary gland. Scintigraphy can be used in the functional evaluation of the gland. Sialendoscopy is comparatively recent advancement that helps with diagnostic as well as interventional endoscopy of salivary glands.

\section{Plain film imaging}

Plain film imaging helps in demonstrating presence of Sialolith and involvement of adjacent osseous structures caused by lesions related (benign or malignant tumor of salivary gland) or not related (inflammatory or neoplastic process of mandible) to salivary glands [2].

\section{Intraoral radiographic methods}

Soft tissue radiograph of upper vestibule against maxillary second molar region using intraoral Periapical film can help locate Sialolith present in anterior Stenson duct of parotid. Occlusal radiographs, i.e. Standard mandibular occlusal radiographs and over the shoulder mandibular occlusal radiographs can be used to diagnose Sialolith in anterior part of submandibular gland duct and posterior part of submandibular gland respectively.

\section{Extraoral radiographic methods}

Extraoral radiographic methods to locate parotid duct include panoramic radiograph and Postero-Anterior (PA) radiograph. In order to avoid superimposition of osseous structure of the region while taking PA radiograph, patient is asked to puff the cheek. Methods to detect submandibular gland duct include Panoramic and Lateral oblique radiograph.

\section{Sialography}

Sialography is method in which contrast medium is injected in salivary gland and following it the gland is imaged with plain radiographs or CT/CBCT. Here plain radiograph is made in three stages. First is scout view which provides baseline image. In second stage radiograph is made after injecting the contrast medium. Last stage is emptying phase in which radiograph is made to confirm the empting of gland. It is contraindicated in patients with acute inflammation, iodine allergy and in patients who are supposed to undergo thyroid function test [3].

\section{Magnetic Resonance Imaging (MRI)}

MRI is modality of choice for soft tissue imaging. It provides superior soft tissue contrast than provided by any other imaging modality. Its benefits include no ionizing radiation and soft tissue contrast. Imaging method of choice for displaying presence of salivary gland mass, its internal structure, its nature, its extension, its perineural spread [4].

\section{Computed Tomography (CT)}

The major salivary glands appear hypodense than surrounding muscles. Coronal section in contrast enhanced CT is best view in visualizing of submandibular and sublingual glands. Imaging with CT helps in detecting acute inflammatory process, abscess, mucocele, cyst, Sialolith and benign and malignant neoplasms [5].

\section{Cone Beam Computed Tomography (CBCT)}

Cone Beam computed tomography can be used with or without sialography to detect presence of Sialolith and to study the ductal morphology of the lesion. CBCT is superior to CT in the fact that it provides information of osseous tissue with lesser radiation exposure and more speed. It, however, cannot provide any information about the soft tissue [6].

\section{Ultrasound}

Ultrasound is inexpensive, easily available, painless, non invasive and nonionizing modality that differentiated solid tumor from cystic mass. It is also helpful in detecting presence of Sialolith. Color dopler USG also helps in detecting nature of lesion based on its vascularity [7].

\section{Scintigraphy}

Scintigraphy takes the advantage of selective uptake of radiopharmaceuticals by salivary gland tissue in various pathological conditions. Injection of i.v. 99MTc- Pertechnate causes concentration and excretion of it in glandular structures like thyroid, salivary glands and mammary glands. Based on presence 
of increased, decreased or absence of uptake the condition is diagnosed as inflammatory or neoplastic condition [8].

\section{Sialendoscopy}

Latest edition in imaging modalities of Salivary glands, this method uses Fiberoptic endoscopic principles in salivary gland. In this method the sialendoscope is inserted in major salivary gland duct opening to visualize live ductal and glandular condition. In addition to diagnose the condition it also helps in intervention in form of irrigation, medication delivery, lithotripsy and use of basket to remove the smaller Sialoliths [9].

\section{Conclusion}

Imaging the salivary gland is important aspect of management of salivary gland disorders. Selection of appropriate imaging method and accurate interpretation of images will help in correct diagnosis of condition.

\section{References}

1. Pharoah MJ, White SC (2000) Oral Radiology Principles and Interpretation. ( $4^{\text {th }}$ edn) St. Louis, Mosby, USA p. 53.

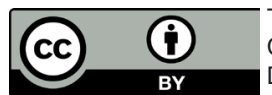

This work is licensed under Creative Commons Attribution 4.0 License

DOI: 10.19080/ADOH.2018.08.555745
2. Liyanage SH, Spencer SP, Hogarth KM, Makdissi J (2007) Imaging of salivary glands. Imaging 19: 14-27.

3. Drage NA, Brown JE (2009) Cone beam computed sialography of sialoliths. Dentomaxillofacial Radiology 38(5): 301-305.

4. Kalinowski M, Heverhagen JT, Rehberg E, Klose KJ, Wagner HJ (2002) Comparative Study of MR Sialography and Digital Subtraction Sialography for Benign Salivary Gland Disorders. AJNR Am J Neuroradiol 23(9): 1485-1492.

5. La'Porte SJ, Juttla JK, Lingam RK (2011) Imaging the floor of the mouth and the sublingual space. Radio Graphics 31(5): 1215-1230.

6. Jayachandran S, Joshi B (2017) Suppurative Parotitis with Multiple Sialoliths. J Dent Oral Biol 2(16): 1097.

7. El Khateeb SM, Abou Khalaf AE, Farid MM, Nassef MA (2011) A prospective study of three diagnostic sonographic methods in differentiation between benign and malignant salivary gland tumours. Dentomaxillofacial Radiol 40(8): 476-485.

8. Shah VN, Branstetter BF (2007) Oncocytoma of the parotid gland: A potential false-positive finding on 18F-FDG PET. AJR Am J Roentgeol 189(4): W212-W214.

9. Nahlieli O, Baruchin AM (1977) Sialoendoscopy: three years' experience as a diagnostic and treatment modality. J Oral Maxillofac Surg 55(9): 912-918.

\section{Your next submission with Juniper Publishers} will reach you the below assets

- Quality Editorial service

- Swift Peer Review

- Reprints availability

- E-prints Service

- Manuscript Podcast for convenient understanding

- Global attainment for your research

- Manuscript accessibility in different formats

( Pdf, E-pub, Full Text, Audio)

- Unceasing customer service

Track the below URL for one-step submission https://juniperpublishers.com/online-submission.php 